\title{
IFRS CONVERGENCE AND EARNINGS MANAGEMENT
}

\author{
Trisninik Ratih Wulandari, Juliati, Arum Kusumaningdyah Adiati \\ Email: trisninik_rw@yahoo.com \\ UNS Surakarta
}

\begin{abstract}
This study aims at providing empirical evidence about the impacts of IFRS convergence on earnings management and examining the differences of the level of earnings management between before and after full IFRS convergence.

The research objects were manufacturing companies registered on the Indonesia Stock Exchange (BEI) for 4 years (2010-2013). The sampling technique used was purposive sampling. The number of samples taken from the purposive sampling for each year was 85 companies. The main variables used in this study were IFRS and earnings management. The hypothesis analysis used multiple regression analysis of data by using discretionary accruals developed by Jones (1991) and the analysis of t-test difference test.

The results show no difference between the earnings in the period of before and after convergence. The results of the difference test analysis also reveal that there is no difference in the level of earnings management between the period of before and after convergence. Based on this study it can be concluded that the IFRS convergence does not guarantee a decrease in earnings management of manufacturing companies listed on BEI.
\end{abstract}

Keywords: earnings management, IFRS convergence, discretionary accrual

\section{INTRODUCTION}

Globalization

development of Multi National Corporations (MNC). When the business world is becoming borderless there will be problems emerging if the accounting standard used in a particular country differs from the one used in other countries. This issue leads to the emergence of the need for international accounting standards to facilitate investors/ potential investors and creditors/ potential creditors in understanding financial reports presented by each company in different countries. Therefore several world organizations such as the IASB (International Accounting Standards Board), EC (Europe Commission),
IOSCO (International Organization of Securities Commissions), IFAC (International Federation of Accountants) propose the idea to establish international accounting standards known as IFRS (International Financial Reporting Standards).

International Financial Reporting Standards (IFRS), formerly known as International Accounting Standards (IAS), was issued to achieve the objective of preparing high quality international financial reporting standards. A number of studies have shown that the IFRS convergence can improve the quality of accounting information, one of which is shown by a decrease in earnings management in some countries (Capkun et 
al., 2007, Liu and Liu, 2007, Barth et al., 2008 Chen et al., 2010, Chua et al., 2012 and Kargin 2013).

Indonesia as one of the G20 countries decided to conduct PSAK (Statement of Financial Accounting Standard) convergence with IFRS. IFRS convergence as a whole is effective and mandatory for all companies that have gone public since January 1, 2012.

Cai et al. (2008) state that one of the objectives of IFRS establishment by the IASB is to simplify various alternatives of permitted accounting policies that are expected to limit the management's discretions towards profit manipulation. Various studies have been conducted to examine the impacts of IFRS convergence on earnings management in both manufacturing and banking sectors. One of them is the study conducted by Wang and Campbell (2012) which reveals that the IFRS convergence lowered earnings management but this evidence is not strong enough and still needs further research. Lin and Paananen (2006) examined changes in the pattern of earnings management activities and stated that the IASB was not effective in reducing overall earnings management activities. Callao and Jarne (2010) compared the discretionary accrual of companies listed on 11 European stock markets shortly after IFRS converging. They discovered that the IFRS supported discretionary accounting and opportunistic behavior. Rudra and Bhattacharjee (2012) examined whether IFRS affected earnings management in India and found that earnings management increased significantly because of the IFRS convergence. Meanwhile in Indonesia, Widhiastuti's study (2011) shows that there is a decrease in the relevance value of accounting information due to earnings management in manufacturing companies post IFRS convergence. In addition to manufacturing companies there are several studies examining the banking sector. Research on the effect of IFRS convergence on the level of earnings management in the banking sector has been done by Santy et al. (2012) resulting a conclusion that IFRS convergence has no significant effect on earnings management and that there is no difference in the level of earnings management significantly between before and after IFRS convergence. The level of earnings management in a company's financial statements can be shown by calculating (discretionary accruals) or accrual policy arising from management policies. Discretionary accruals calculation is performed by employing accrual aggregate measurements modified by Jones (Rudra, 2012). In addition to IFRS convergence, there are several other factors that need to be controlled in calculating earnings management such as company size, financial leverage, market to book value and institutional investors (Rudra, 2012).

This research would analyze the impact of IFRS convergence on earnings management in companies registered on the Indonesia Stock Exchange. The data used in this study were the financial statements of Indonesian manufacturing company registered on the Indonesia Stock Exchange from 2010 until 2013. 2010 and 2011 data were used as the data prior to the 
convergence of IFRS, whereas the financial statements in 2012 and 2013 as the data of the period after IFRS convergence. The reason for using 2010 and 2011 as observation data before convergence and in 2012, 2013 as the data after IFRS convergence is because IFRS convergence became effective and was mandatory for go public companies as of January 1, 2012.

The objective of this study is to provide empirical evidence about the effect of the IFRS convergence on earnings management and examine the differences in the level of earnings management before and after the IFRS convergence in companies registered on the Indonesia Stock Exchange in Indonesia. Earnings management in this research utilized discretionary accrual proxy developed by Jones (1991).

This study is expected to be one of information sources for readers and an additional literature for further research on the impact of IFRS convergence on the quality of accounting information projected by earnings management. It is also expected that this study can contribute for regulators, in this case the Board of Financial Accounting Standard (DSAK) in relation to IFRS convergence benefits for improving the quality of accounting information.

\section{LITERATURE REVIEW AND HYPOTHESIS DEVELOPMENT} Agency Theory

Jensen and Meckling (1976) define an agency relationship as a contract between one or more persons (the principal) by engaging another person (the agent) to provide services on their behalf that involves the delivery of some decisionmaking authority to the agent. Principals are shareholders or owners who can give a mandate to the agent to act on behalf of the principal, while the agents are the management who are given a mandate by the principal to act on behalf of the principal and are required to account for the actions taken to the principal. The Agency Theory describes the conflict between the management as an agent with the owner as the principal who can be detrimental to both sides. In that regards, manager as an agent who holds the power of the principal normally tends to perform dysfunctional behavior. The reason is because of the asymmetry of information in the presenting financial statements.

The difference of interest between the principal and the agent in the agency theory leads to the asymmetry of information. Asymmetry of information is the uneven distribution of information between the agent and the principal resulting in an imbalance of information receipt between the two. The forms of information asymmetry are moral hazard and adverse selection. The manager has more information than the principal does. In order for the principal to assess manager's performance properly, a measuring instrument in the form of financial statement is needed. The content of the statement should be disclosed (full disclosure) so that the principal can be accurate in decision-making and the quality of accounting information can be held accountable (Scott, 2009: 1-18). 


\section{Earnings Management}

Earnings management has been exhaustively defined by researchers. Scott (2006) defines earnings management as a way of presenting the profit that aims to maximize the utility of management and or to increase market value through the selection of accounting procedure policy set by the management. There are two perspectives in understanding the earnings management carried out by company managers: firstly, it is aimed at maximizing management utility (opportunistic behavior). Secondly, it aims to share the earnings to all parties involved in the contract (efficient contracting). Fisher and Rosenzberg define earnings management as an action of managers serving financial statements by raising (or lowering) the profit during an on-going period of business units for which they are responsible, without causing increase (decrease) of the economic profitability of a particular unit in a long term. Healy and Wahlen in Ujiyantho and Scout (2007) describe that earnings management occurs when managers use judgment in financial reporting and transactions depreciation to alter financial statements for the purpose of manipulating the amount (magnitude) of earnings to some stakeholders about the economic performance of companies or to influence the results of agreement (contract) which depend on the figures in the accounting reported.

According to Scott (2006), there are several motivation to perform earnings management, namely: bonus program motivation, motivation to achieve the expectations of investors, debt contracts motivation, and IPO (Initial Public Offering) motivation. Meanwhile, Bryshaw and Eldin (1989) found that the reason that management did earnings management are: (1) management compensation schemes linked to the performance of the company presented in the accounting profit reported; as well as (2) fluctuations in the management's performance can trigger interventions by owners to replace the management with a direct takeover. According to Wild et al. (2007), there are three types of earnings management strategies namely: income increasing, big bath and income smoothing. Watts, Zimmerman 1986 in Pramudji, Trihartati, 2010) claim that motivation for earnings management, among others are: 1) Bonus plan hypothesis in which profit serve as the basis in providing bonuses to employees. For example, when profit is used as a benchmark in providing bonuses, it will create the impetus for managers to organize financial data in order to receive the bonus as desired 2) Debt (equity) hypothesis confirms that companies with bigger debt to equity ratio tend to choose accounting procedures that enable them to raise their profit 3) Political hypothesis cost, companies tend choose accounting methods that can lower reported net profit. Earnings management conducted by managers will decrease the quality of the earnings. Earnings management will cause earnings capability in predicting future earnings to shrink.

According to Gunny (2005) earnings management can be classified into three categories, namely: fraudulent accounting, accruals management and 
real earnings management. Fraudulent accounting is an accounting alternative that violates general accepted accounting principles (GAAP), accrual earnings management includes a variety of options in the GAAP covering the real economic performance and real earnings management occurs when managers perform actions that deviate from the actual practice to boost reported earnings. Furthermore Roychowdhury (2006) classified real earnings management into three, namely: the manipulation of sales, large-scale production and reducing discretionary costs.

Cohen and Zarowin (2008) argue that companies that manage higher earnings are likely to have one or all of the various characteristics below: unusually low operational cash flow, unusually low discretionary cost, and unusually high production costs.

\section{IFRS (International Financial Reporting Standards)}

International Financial Reporting Standards (IFRS) is a standard of financial reporting compilation which is encouraged to be implemented by many countries in the world in regard to convergence towards the realization of the use of the same standard. Becoming effective in 2012, IFRS is the international accounting standards issued by the International Accounting Standards Board (IASB). The structure of international standards establishment consists of four organizations: the International Accounting Standards Committee Foundation, $\mathrm{T}$ he International
Accounting Standards Boards (IASB), a Standards Advisory Council and International Financial Reporting Interpretations Committee (IFRIC). IFRS has been adopted by several countries, such as Canada, Australia and European countries. Even today, countries that did not converge like the United States are expected to have adopted IFRS as soon as 2014. The use of IFRS also aims to improve the quality of accounting. IFRS is issued by the International Accounting Standards Board (IASB). Since 2005 many countries are required to adopt IFRS. One of the objectives is to improve the transparency and comparability of financial reporting in different countries. IASB was initially called as International Accounting Standards Committee (IASC). IASC was formed in London, England in 1973 at the time of fundamental changes in the regulations related to accounting.

\section{IFRS Convergence in Indonesia}

IFRS convergence can be done with two kinds of adoption strategy, namely big bang strategy and gradual strategy. Big bang strategy fully adopts IFRS at once, without going through certain stages. This strategy is used by the developed countries. On the other hand, in the gradual strategy IFRS adoption is done gradually. This strategy is used by developing countries such as Indonesia.

The following is the development of the convergence of PSAK to IFRS planned by the Board of Financial Accounting Standards (DSAK) of IAI: 
Table 1

The development of IFRS convergence

\begin{tabular}{lll}
\hline $\begin{array}{l}\text { Adoption Phase } \\
(\mathbf{2 0 0 8}-\mathbf{2 0 1 0})\end{array}$ & $\begin{array}{l}\text { Final Preparation Phase } \\
\mathbf{( 2 0 1 1 )}\end{array}$ & $\begin{array}{l}\text { Implementation Phase } \\
\mathbf{( 2 0 1 2})\end{array}$ \\
\hline $\begin{array}{l}\text { Adoption of the entire IFRS to } \\
\text { PSAK }\end{array}$ & $\begin{array}{l}\text { Completion of the } \\
\text { necessary infrastructure } \\
\text { preparations } \\
\text { Gradual implementation of } \\
\text { some of IFRS-based PSAK }\end{array}$ & $\begin{array}{l}\text { Implementation of IFRS-based } \\
\text { PSAK on a gradual basis }\end{array}$ \\
$\begin{array}{l}\text { Preparation of the necessary of the impact of PSAK } \\
\text { infrastructure }\end{array}$ & $\begin{array}{l}\text { Evaluation and management of the comprehensively } \\
\text { impact of the adoption on the } \\
\text { governing PSAK }\end{array}$ \\
\hline
\end{tabular}

Indonesian Accountants Association (IAI) as an organization that is authorized to establish accounting standards in Indonesia has taken steps to foster uniform accounting standards. Since 1994 the IAI has implemented harmonization programs and the adaptation of international accounting standards in order to develop their accounting standards.

IAI in December 2008 has announced plans of local accounting standards convergence, namely the Statement of Financial Accounting Standards (PSAK) with International Financial Reporting Standards (IFRSs) which is a product of the IASB. This convergence plan was realized in 2012.

Financial Accounting Standards (SAK) per 1 June 2012 issued by the Indonesian Accountants Association (IAI) in 2012 is comprised of 42 Statement of Financial Accounting Standards (PSAK) and 20 Interpretation of Financial Accounting Standards (ISAK). This SAK also explains that there are 11 Revocation of Statement of Financial Accounting Standards (PPSAK) which has prevailed previously. Sharia entities are exclusively regulated in sharia PSAK consisting of 10 sharia PSAK. As for the Small and Medium Enterprises (UKM), they are regulated in the SAK of Entities without Public Accountability (SAK ETAP).

\section{Hypothesis Development}

There have been numerous researches conducted to examine the impact of IFRS adoption on the quality of information and the accounting profit. The empirical studies provide results variously. Research conducted by Barth et al. (2008), Armstrong et al. (2010, Wang and Campbell (2012), Zeghal et al (2012) and Chua et al ( 2012) conclude that the adoption of IFRS can improve the quality of accounting information which is measured by a decrease in profit. Meanwhile study conducted by Lin and Paananen (2006), Callao and Jarne (2010) and Rudra and Bharttachrjee (2012) conclude conflicting results stating that earnings management conducted by companies has increased after the adoption of IFRS.

Results of research in Indonesia also show there are still differences, Widhiastuti (2011) and Santy et al. (2012) in their research explain that the adoption of IFRS 
has no significant effect on earnings management and there is no difference in the level of earnings management significantly between before and after the adoption of IFRS. While the research conducted by Rohmah and Yuni (2013) concludes that the quality of accounting information projected by value relevance will increase after the adoption of IFRS. Likewise, the results of research by Suprihatin and Tresnaningsih (2013) also propose the same results.

One of the objectives of the establishment of IFRS is to equalize the use of rules in accounting practices in different countries, so this can facilitate investors in detecting earnings management performed by companies. Ewert and Wagenhof (2005) state that stricter accounting standards can reduce earnings management and improve the quality of financial reporting. IFRS requires more and more detailed disclosures. Based on the research results and the above explanation it can be hypothesized that:

H1: There are effects of the IFRS adoption on earnings management in manufacturing companies registered on the Indonesia Stock Exchange.

The adoption of principle-based IFRS is expected to reduce the level of earnings management. Wang and Campbell (2012) suggest that the adoption of IFRS lowered earnings management while Rudra and Bhattacharjee (2012) research concludes that the adoption of IFRS positively affect earnings management, but more research will be done in order to obtain more powerful evidence. The adoption of IFRS in previous studies resulted in two directions, i.e. increasing and decreasing earnings management. However, referring to the IAI statement in 2012 it is stated that IFRS may complicate earnings management action through the implementation of fair value and the balance sheet approach. The study assumption is there are differences in the level of earnings management in companies before and after IFRS, companies that adopt IFRS tend to have smaller earnings management. Based on the explanation above it can be concluded:

$\mathrm{H} 2$ : There is a difference in the level of earnings management among companies registered on the Indonesia Stock Exchange before and after the full adoption of IFRS.

\section{RESEARCH METHODS Population and Sample}

The populations used in this study are all companies listed on the Indonesia Stock Exchange (BEI) in 2010, 2011, 2012 and 2013. The final samples were selected using purposive sampling technique that met the following criteria:

1. The company published financial statement data consistently during 2010 until 2013.

2. The company has conducted an Initial Public Offering (IPO) since January 1, 2010.

3. The company uses Indonesian Rupiah (IDR) as the currency

4. The company closed the books on December 31, 2013

5. The data required for this study are available.

This study analyzes the quality of accounting information before and after the adoption of IFRS proxied by earnings management. The adoption of IFRS was particularly used effectively as of January 
1, 2012. Therefore, taking into account the availability of data, the period after the adoption (post IFRS period) was elected 2012 and 2013. Meanwhile, the period before adoption was elected 2010 and 2011 .

The total number of companies listed on the Indonesia Stock Exchange in 2013 was 139 companies (idx statistical quarter 1 2014). But the amount of the final sample used after purposive sampling remained 85 companies. It can be shown in Table 1 . The number of initial observations in 2010, 2011, 2012 and 2013 was the same amounting to 139 companies. After investigation it turned out that companies conducting an IPO prior to January $1^{\text {st }}$ 2010 were 27 companies, the companies that did not use IDR currency were 24 and the companies closed the books not on December 31 were 3 companies. Samples temporarily used were 85 companies for each of the year 2010, 2011, 2012 and 2013. So the total observations used before and after the adoption were 170 companies. The research data was obtained from various sources that complement each other like the financial report of the companies, IDX Fact Book, ICMD, and monthly stock price of BEI website

Table 1

Sample Selection Procedures

\begin{tabular}{|c|c|c|c|c|}
\hline Description & 2010 & 2011 & 2012 & 2013 \\
\hline $\begin{array}{l}\text { The number of companies listed on the Indonesia } \\
\text { Stock Exchange in } 2013 *\end{array}$ & 139 & 139 & 139 & 139 \\
\hline $\begin{array}{l}\text { Companies that conducted IPO prior to January 1, } \\
2010\end{array}$ & $(27)$ & $(27)$ & $(27)$ & $(27)$ \\
\hline Companies that do not use IDR currency & $(24)$ & $(24)$ & $(24)$ & $(24)$ \\
\hline Companies that close the book not on December 31 , & (3) & (3) & (3) & (3) \\
\hline Number of observations of the final sample & 87 & 87 & 87 & 87 \\
\hline
\end{tabular}

* Idx _ statistic first quarter of 2014

\section{Operational Definition and}

\section{Measurement of Variables}

\section{Accounting Information Quality Metrics}

The quality of accounting information is now getting more attention and is the center of debate for investors, regulators and researchers. The quality of accounting information is a multi-dimensional concept, and there is no definition agreed in accounting literature. Some metrics has been developed to assess the quality of accounting information such as earnings management, timeliness of loss and the value relevance (Liu and Liu, 2007; Barth et al., 2008; Paananen and Lin, 2009; Kousenidis et al., 2010; Kwong 2010; Outa 2011; Agostino 2011; Zeghal et al (2012), Chua et al. 2012 and Kargin 2013).

The quality of accounting information in this study uses a earnings management proxy, which is proxied by discretionary accruals by employing an aggregate accrual approach model of Jones (1991). 


\section{Measurement Variable}

This study uses three types of variables i.e. independent variables and the dependent variable. Independent variables use IFRS. The measurements of these variables use dummy variables which are given a zero for companies that have not implemented PSAK 2012 and a one for companies that have applied PSAK 2012.

The dependent variables in this study are earnings management proxied with discretionary accrual using the aggregate accrual approach model of Jones (1991). The use of discretionary accruals as an earnings management mechanism can be calculated as follows:

1. Using Modified Jones Model TAC $=$ Nit - CFOit

2. The value of total accrual (TA) were estimated by OLS regression equation as follows:

TACit $=\beta 1(1 /$ Ait- 1$)+\beta 2(\Delta$ Revt $/$ Ait $-1-$ $\Delta$ Rect/Ait-1) $+\beta 3$ (PPET/Ait-1)

3 . Using the regression coefficient above the value of nondiscretionary accruals (NDA) can be calculated using the formula:

NDAit $=\beta 1(1 /$ Ait- 1$)+\beta 2(\Delta$ Revt / Ait1- $\Delta$ Rect / Ait-1) + $\beta 3$ (PPET / Ait-1)

4. Discretionary accrual (DA), can be calculated as follows:

DAit $=$ TACit - NDAit

Descriptions:

DAit = Discretionary accruals of company $i$ in $t$ period

NDAit $=$ Non discretionary accruals of company $\mathrm{i}$ in $\mathrm{t}$ period

TACit = Total accrual of company $\mathrm{i}$ in $t$ period
Nit $=$ Net profit of company $i$ in $t$ period

CFOit = Cash flow of operational activities of company $i$ in $t$ period

Ait-1 = Total assets of company $i$ in $t$ period

$\Delta$ Revt $=$ Revenue changes of company $i$ in t period

PPEt = Fixed assets of company $\mathrm{i}$ in t period

$\Delta$ Rect $=$ Receivable changes of company $i$ in $t$ period

Control variables used in this study consisted of Financial Leverage (D /E), firm's size (size), Market-to-book ratios $(\mathrm{M} / \mathrm{B})$ and equity holding by institutional investors (II) in the company as the control variable.

Size $=$ Market Capitalization

$\mathrm{D} / \mathrm{E}=$ Total debts divided by total equity

$\mathrm{M} / \mathrm{B}=$ Market value of equity divided by the book value of equity

$\mathrm{II}=$ Percentage of common stock owned by institutional investors

\section{Research Methods}

The methods of data analysis utilizes two models, the first model is to examine the impact of IFRS adoption on earnings management through multiple linear regression and the second model is to test differences in the level of earnings management before and after the full adoption (the application) of IFRS by using t-test difference test. Results of the research are descriptive statistical analysis and hypothesis testing technique.

$\mathrm{DA}=\beta 0+\beta$ 1IFRS $+\beta+\beta$ 2SIZE 3D / E $+\beta 4 \mathrm{M} / \mathrm{B}+\beta 5 \mathrm{FII}+\mathrm{e}$

Descriptions:

DA $=$ Discretionary Accruals 
IFRS $=$ IFRS convergence, 1 if converging IFRS and 0 if not doing the convergence

Control Variables $=$ Size, Debt to Equity Ratio, Market to Book ratio, Institutional Investors

The analysis of the data in this study uses descriptive statistics, classic assumption testing, and hypothesis testing.

\section{RESEARCH RESULTS}

\section{Descriptive Statistics Analysis}

Based on Table 2, the results of descriptive statistics indicate that mean of discretionary accruals of manufacturing company is 4.96 with a standard deviation of 0.68 . The value of maximum discretionary accruals is 7.00 and the minimum value of discretionary accruals is 2.94. IFRS is dummy variable which means that the value of 1 is used if companies apply IFRS and the value of 0 is used if companies have not applied IFRS. 174 samples scored one in 2012-2013 when the application of IFRS has been enforced and other 174 samples obtained zero in the $2010-2011$ when the mandatory implementation of IFRS has not been implemented by companies listed on the Indonesia Stock Exchange. The mean value of the IFRS is 0.48 with a standard deviation of 0.50 . The size of manufacturing companies on mean is at 4.87 with a standard deviation of 1.48 . The maximum value of the size of the companies is 7.84 and the minimum value of the size of the companies is 0.5. The highest value of $\mathrm{D} / \mathrm{E}$ ratio is 18.28 and the lowest one is -10.34 . The mean value of $\mathrm{D} / \mathrm{E}$ ratio is 1.3 with a standard deviation of 2.20. The lowest value of $\mathrm{M} / \mathrm{B}$ is -9.27 and the highest one is 47.27 . The mean $\mathrm{M} / \mathrm{B}$ value of the companies is 2.84 with a standard deviation of 5.99. The mean value of institutional ownership of manufacturing companies is overall at the number of 2.88 with a standard deviation of 14.18.

Table 2

Descriptive Statistics

\begin{tabular}{lrrrrr}
\hline & N & \multicolumn{1}{c}{ Minimum } & Maximum & \multicolumn{1}{l}{ Mean } & \multicolumn{1}{l}{$\begin{array}{l}\text { Std. } \\
\text { Deviation }\end{array}$} \\
\hline DA & & & & & .67862870 \\
x1 (IFRS) & 340 & 2.93840 & 7.00853 & $4.9461713 \mathrm{E} 0$ & .50052 \\
x2 (Size) & 340 & .00 & 1.00 & .4853 & 1.48363 \\
x3 (D/E) & 340 & .50 & 7.84 & 4.8742 & 2.19930 \\
x4 (M/B) & 340 & -10.34 & 18.28 & 1.3002 & 5.98678 \\
x5 (II) & 340 & -9.27 & 47.27 & 2.8411 & 14.18454 \\
\hline \hline
\end{tabular}

Valid N

340

(listwise)

DA: Discretionary Accrual, size: company, $D / E$ : financial leverage, $M / B$ : market to book ratio dan II: institutional investors

\section{Results of hypothesis testing}

Based on the results of $t$ statistical testing in Table 3 for the first hypothesis testing it can be concluded that the independent variable which is IFRS is not significant to earnings management. The significance value obtained is 0.343 which is bigger than 0.05 . The variabel financial leverage $(\mathrm{D} / \mathrm{E})$ insignificant because significance value 0.555 is bigger tahan 0.05 . The variable 
of institutional investors (II) also appears insignificant, in which the significance level value is 0.830 ( $p>0.05)$. It indicates that the IFRS variable, financial leverage and institutional investors do not have significant effects on the changes (variance) of earnings management. As for the other three control variables, they have significantly positive influence on earnings management i.e. the size variable that indicates significance level value of 0.000 ( $\mathrm{p}$ <0.05). Market to book value variable shows significantly influence on the earnings management with a significance level value amounted to 0.004 $(\mathrm{p}<0.05)$.

Table 3

Hypothesis Testing

\begin{tabular}{lrrr}
\hline & \multicolumn{3}{c}{ Nilai P } \\
\cline { 2 - 4 } Variabel & Koefisien & .000 \\
\hline Konstanta & 32.906 & .343 \\
IFRS & .950 & .000 \\
SIZE & 7.103 & .555 \\
D/E & .591 & .004 \\
M/B & 2.893 & .830 \\
II & .214 & $\mathbf{0 . 0 0 0}$ \\
Nilai F & $\mathbf{1 5 . 5 4 9}$ &
\end{tabular}

Based on the results of t-test difference test, the second hypothesis testing shows the mean value of discretionary accruals in the period before the adoption of IFRS amounts to 4.87 while the average value of discretionary accruals in the period after the adoption of IFRS amounts to 4.99. Probability significance value (sig 2-tailed) of 0.1 is greater than the significance level $\alpha=0.05$, so it can be concluded that there are absolute differences in the mean value of discretionary accruals, statistically there is significant difference.

\section{CONCLUSIONS AND SUGGESTIONS}

This study aims at providing empirical evidence about the impacts of IFRS convergence on earnings management and examining the differences of the level of earnings management between before and after the IFRS convergence in companies listed in the Indonesia Stock Exchange in
Indonesia. The earnings management in this study uses a proxy of discretionary accruals developed by Jones (1991). Based on the findings in this study that specifically examine manufacturing sector, it can be concluded that the adoption of IFRS has no effect on earnings management. The enactment of IFRS does not indicate that there is a decrease in earnings management. The results of difference testing analysis conducted shows that statistically there are significant differences of earnings management level between before and after the adoption of IFRS.

Future research can be developed by examining the impact of IFRS adoption on the quality of accounting information with a focus on one of the standards adopted. In addition, further research could also consider other variables such as corporate governance and ownership level as 
moderating variables of the correlation between the adoption of IFRS and relevance value. It is also suggested that future research examine companies engaged in sectors other than manufacturing industry and use different time sequences.

\section{REFERENCES}

Agostino, M., Drago, D., . Silipo, D. 2011. The Value Relevance of IFRS in the European Banking Industry. Review Quantity Finance Accounting 36:437-457.

Armstrong, C. S., M. E. Barth, A. D. Jagolinzer, and E. J. Riedl. 2010. Market reaction to the adoption of IFRS in Europe. Accounting Review 85 (1): 31-61.

Ashbaugh, H., dan M. Pincus. 2001. Domestic Accounting Standards, International Accounting Standards, and the Predictability of Earnings. Journal of Accounting Research 39: 417-434.

Ball, R., A. Robin, dan J. S. Wu. 2003. Incentives Versus standards: Properties of Accounting Income in Four East Asian Countries. Journal of Accounting \& Economics 36: 235-270.

Ball, R., S. P. Kothari, dan A. Robin. 2000. The Effect of International Institutional Factors on Properties of Accounting Earnings. Journal of Accounting \& Economics 29: 1-51.

Barth, M., W. Landsman, dan M. Lang. 2008. International Accounting Standards and Accounting Quality.
Journal of Accounting Research 46(3): 467-498.

Cahyonowati, N., dan Ratmono, D. 2012. Konvergensi IFRS dan Relevansi Nilai Informasi Akuntansi. Jurnal Akuntansi dan Keuangan, 11(2): 105-115.

Callao, S., Jarne, J., dan La'inez, J. 2007. Adoption of IFRS in Spain: Effect on the Comparability and Relevance of Financial Reporting. Journal of International Accounting, Auditing and Taxation 16: 148-178

Capkun, V., A. Cazavan-Jeny, T. Jeanjean, dan L. Weiss. 2008. Earnings Management and Value Relevance during the Mandatory Transition to IFRS in Europe. Working paper, HEC Paris, ESSEC Business School, and The Fletcher School. Available at: http://papers.ssrn.com/sol3/papers.cfm ? abstract_id $1 / 41125716$

Christensen, H. B., E. Lee, dan M. Walker. 2008. Incentives or Standards: What Determines Accounting Quality Changes around IFRS Adoption? Working paper, Manchester Business School.

Chua, Y., Cheong, C. dan Gould, G. 2012. The Impact of Mandatory IFRS Adoption on Accounting Quality: Evidence from Australia. Jounal of International Accounting Research, 11(1): 119-146.

Daske, H., L. Hail, C. Leuz, dan R. Verdi. 2008. Mandatory IFRS reporting around the World: Early evidence on the economic consequences. Journal of Accounting Research 46: 1085-1142. 
Deloitte. 2007. IFRS and Indonesian GAAP: A Comparison. New York, NY: Deloitte.

Outa. Erick. 2011. The Impact of International Financial Reporting Standards (IFRS) Adoption on the Accounting Quality of Listed Companies in Kenya. International Journal of Accounting and Financial Reporting 1(1) : 212-241.

Ewert, R, dan A. Wagenhofer. 2005. Economic Effects of Tighttening Accounting Standards to Restrict Earning Management. The Accounting Review. Vol. 80: 1100-1124

Ewert, R., dan A. Wagenhofer. 2010. Earnings Quality Metrics and What They Measure. Working paper, University of Graz. Financial Reporting Council (FRC). 2002. Adoption of International Accounting Standards by 2005. Bulletin of the Financial Reporting Council. ACT, Australia: FRC.

Ghozali, Imam. 2012. Aplikasi Analisis Multivariate dengan Program IBM SPSS 20, Edisi 6. Badan Penerbit Universitas Diponegoro. Semarang.

IDX Fact Book. Diunduh dari www.idx.co.id

IDX Statistik. Diunduh dari www.idx.co.id

Ikatan Akuntansi Indonesia. 2012. Standar Akuntansi Keuangan per I Juni 2012.

Jeanjean, T., dan H. Stolowy. 2008. Do Accounting Standards Matter? An Exploratory Analysis of Earnings Management before and after IFRS
Adoption. Journal of Accounting and Public Policy 27: 480-494.

Jensen, M., dan W. Meckling. 1976. Theory of the Firm: Managerial Behavior, Agency Costs and Ownership Structure. Journal of Financial Economics 3: 305-360.

Jones, J.J. 1999. Earning Management during import relief investigations. Journal of Accounting Research (Autumn): 1993-228

Karampinis, N. dan Hevas, D. 2011. Mandating IFRS in an Unfavorable Environment: The Greek Experience. The International Journal of Accounting, 46, 304-332.

Kargin, S. 2013. The Impact of IFRS on the Value Relevance of Accounting Information: Evidence from Turkish Firms. International Journal of Economics and Finance, 5 (4): 71-80.

Kousenidis, D., Ladas, A. dan Negakis, C. 2010. Value Relevance of Accounting Information in the Pre- and Post-IFRS Accounting Periods. European Research Studies, 13(1): 145-154.

Kwong, L. 2010. The Value Relevance of Financial Reporting in Malaysia: Evidence from Three Different Financial Reporting Periods. International Journal of Business and Accountancy, 1(1): 1-19.

Leuz, C., Nanda, D., dan Wysocki, P. 2003. Earnings Management and Investor Protection: an International Comparison. Journal of Financial Economics 69 : 505-527 
Liu, J., dan Liu, C. 2007. Value Relevance of Accounting Information in Different Stock Market Segments: The Case of Chinese A-, Band H-shares. Journal of International Accounting Research, 6(2): 55-81.

Ohlson, J. 1995. Earnings, Book Values And Dividends in Quality Valuations. Contemporary Accounting Research, 11: 661-688.

Othman, H., dan Zeghal, D., 2006. A Study of Earnings-Management Motives in the Anglo-American and Euro-Continental accounting models: The Canadian and French cases. The International Journal of Accounting 41 : 406-435

Paananen, M., dan H. Lin. 2009. The development of accounting quality of IAS and IFRS over time: The case of Germany. Journal of International Accounting Research 8(1): 31-55.

Badan Pengawas Pasar Modal. 2012. Peraturan Bapepam No : X.K.2 Tentang Penyampaian Laporan Keuangan Berkala Emiten atau Perusahaaan Publik.diunduh dari www.bapepam.go.id.

Rohmah, A., dan Yuni, R. 2013. Dampak Penerapan Standar Akuntansi Keuangan (SAK) Pasca Konvergensi
IFRS terhadap Relevansi Nilai dan Asimetri Informasi. Prosiding Simposium Nasional Akuntansi (SNA) XVI, Manado.

Santy, Prima. Tawakkal dan Grace T Pontoh. 2012. Pengaruh Konvergensi IFRS terhadap Manajemen Laba pada Perusahaan Perbankan di Bursa Efek Indonesia.

Scott, W. 2009. Financial Accounting Theory. University of Waterloo Queen"s University. Pearson. Prentice Hall. Toronto.

Shima, Kim M., dan Yang, David C. 2012. Factors Affecting the Adoption of IFRS. International Journal of Business 17: 276-298.

Suprihatin, S., dan Tresnaningsih, E. 2013. Pengaruh Konvergensi International Financial Reporting Standards terhadap Relevansi Nilai Informasi Akuntansi: Studi Empiris pada Perusahaan yang Terdaftar di BEI. Prosiding Simposium Nasional Akuntansi(SNA) XVI, Manado.

Zeghal, D., Chtourou, S.,dan Fourati. 2012. The Effect of Mandatory Adoption of IFRS on Earnings Quality: Evidence from the European Union. Journal of International Accounting Research, 11(2): 1-25 